\title{
VIRAL HEPATITIS C PATIENTS; HYPOTHYROIDISM WITH RELATION OF INTERFERON TREATED PATIENTS dr_santosh72@yahoo.com
}

1. Post Graduate JPMC Karachi

2. Assistant Prof.

LUMHS Nephrology Ward

3. Assistant professor

Medicine Department LUMHS

4. Assistant Professor Nephrology LUMHS.

Correspondence Address: Dr. Santosh Kumar

Assistant Professor

Medicine Department

LUMHS.

dr_santosh72@yahoo.com

Article received on: 26/06/2016

Accepted for publication: 30/08/2016

Received after proof reading: $07 / 10 / 2016$
Dr. Aisha Rajput', Dr. Bagwan Das², Dr. Santosh Kumar ${ }^{3}$, Dr. Rafique Ansari", Dr. Beshan Kumar ${ }^{5}$, Abdul Qadeer ${ }^{6}$

ABSTRACT... Objectives: To determine the frequency of hypothyroidism in patients with viral hepatitis receiving interferon treatment. Study Design: Descriptive cross sectional. Setting: Department of Medicine, Jinnah Postgraduate Medical Centre, Karachi. Duration of Study: Six months. Subjects and Methods: All patients with age 30 to 60 years of either gender having persistent or intermittent elevation of alanine arninotransferase (ALT, the upper limit of normal ALT is $40 \mathrm{IU} / \mathrm{L}$ ) over a six-month period and Anti-HCV positivity and detection of HCV-RNA in the sera On IFN- $\alpha$ mono therapy for more than 3 months were enrolled. History of duration of disease and treatment was obtained from patients. A 3 cc blood sample of Patients were drawn and send for TSH level. Presence of TSH level $>4.0 \mathrm{miU} / \mathrm{L}$ was labelled as Hypothyroidism. Results: Mean age of the patients was $51.79 \pm 7.96$ years. There were $51(43.60 \%)$ males and 66 $(56.40 \%)$ females. Mean TSH level was 3.98 $\pm 0.23 \mathrm{mIU} / \mathrm{L}$. Mean duration of HCV was $6.42 \pm 1.67$ months. Mean duration of treatment was $5.42 \pm 1.67$ months. Frequency of hypothyroidism was found in 62 (53\%) patients. Conclusion: The frequency of hypothyroidism in patients with viral hepatitis receiving interferon treatment was found to be $62(53 \%)$.

Key words: $\quad$ Hypothyroidism, Interferon, Viral Hepatitis.

Article Citation: Rajput A, Das B, Kumar S, Ansari R, Kumar B, Qadeer A. Viral Hepatitis C patients; Hypothyroidism with relation of interferon treated patients. Professional Med J 2016;23(10):1263-1268. DOI: 10.17957/TPMJ/16.3481

\section{INTRODUCTION}

Worldwide prevalence of chronic hepatitis c viruses is more found in developing and under developed country where overcrowding, poverty, illiteracy, unhygienic, and basic health care system is disturbed. more then 200 million people are infected hcv viruses all over the world. Hepatitis $\mathrm{c}$ virus is is zoonotic transmitted from chimpanzee due to human contact with animal. Hepatitis $c$ viruses is very common problem in Pakistan and all over world more than thousands death reported every day from different complication. ${ }^{1,2}$ there are five different types of genotype hcv viruses, like genotype type $1,2,3,4,5$. In Pakistan genotype 2 and 3 are more common type of genotype found in all male and female patients while hcv genotype ${ }^{1,3,5}$ more found in other part of world. All hcv virus are more sensitive to interferon therapy with ribaviron, $80 \%$ percent sustained viral response within 6 month in genotype 2 and 3.,4 Multiple study from all over world suggest that interferon and ribaviron therapy is well tolerated in Hcv type 2 and 3 chronic liver disease in Asia and Pakistan. But there few side effect of interferon is more found during six month course of treatment. ${ }^{5-7}$ Isolated interferon therapy has been demonstrated with many adverse drugs effect like depression, bone marrow suppression, iron deficiency anemia, hair loss (alopecia), and mostly in our society of Pakistan we found hypothyroidism and hyperthyroidism is more common side effect in interferon treated patients, so before start a interferon therapy we should take proper history, examination with laboratory reports to rule out thyroid abnormality. $8-10$ Interferon's anti viral drugs directly inhibits the enzyme pathway of thyroid hormone metabolism which leads abnormality increase or decrease triiodo-thyroninie and tetra-iodo-thyroninie level in blood, but prevalence of hypothyroidism is more found in all study of Asia and Europe. 10,11,12,14,16 Out of 68 patients $38(55.9 \%)$ had TSH level $>5 \mathrm{mIU} / \mathrm{L}$ that is Hypothyroidism. ${ }^{17}$ Whereas in other study 1 out of 32 that is $3.12 \%$ developed hypothyroid. 
So interferon related adverse effect have different variability but we observe that prevalence of hypothyroidism are more common in our society. In Pakistan genotype 2-3 hcv chronic liver disease treated with interferon from 3 to 6 month course we found that hypothyroidism are more common than other endocrine problem. So my study shows that to prevent or minimize complication of interferon or hypothyroidism, we must take proper history examination and investigation to avoid from future adverse effect of interferon. ${ }^{18,19}$

\section{MATERIAL AND METHODS}

\section{STUDY DESIGN}

Descriptive cross sectional

\section{SETTING}

Department of Medicine, Jinnah Postgraduate Medical centre, Karachi.

\section{DURATION OF STUDY}

Six months

\section{Inclusion criteria}

- $\quad$ Hepatitis c viruses pts with raised SGPT level with no complication.

\section{- $\quad$ Age 30 to 60 years}

- $\quad$ Either gender

\section{Exclusion Criteria}

- Chronic liver disease due to non hcv and hbv

- Auto immune hepatitis

- Wilson disease

- Haemochromotosis and primary biliary cirrhosis

\section{SAMPLE SIZE}

Prevalence hypothyroidism in $\mathrm{HCV}$ patients on interferon theraphy $=55.9 \%(17)$

Absolute precesion $=9 \%$

Confidence level $=95 \%$

Sample size $=117$ patients

\section{DATA COLLECTION}

Approval for research was obtained from the Ethics Committee of the institute. Patients on IFN-a mono therapy for more than 3 months in a dose ranged 3 to $5 \mathrm{MIU}$ thrice weekly meeting the inclusion criteria was enrolled in the study through OPD and informed consent was taken. History of duration of disease and treatment was obtained from patients. A $3 \mathrm{cc}$ blood sample of Patients were drawn and send for TSH level. Presence of TSH level $>4.0 \mathrm{miU} / \mathrm{L}$ was labelled as Hypothyroidism. This information along with demographics was noted in the proforma attached as annexure.

\section{DATA ANALYSIS}

Data entered and analysis were done on SPSS version 20. Mean \pm SDwas computed for age, $\mathrm{TSH}$ level, duration of HCV and treatment. Frequency and percentage was calculated for gender, occupation and hypothyroidism. as mentioned above), Effect modifiers was addressed through stratification of age, gender, duration of HCV and duration of treatment occupation to see the effect of these on outcomes, applying Chi square test and taking $p$ value $\leq 0.05$ as significant.

\section{RESULTS}

A total number of patients 117 out of them 51 (43.60\%) males and 66 (56.40\%) females shown Figure-2. Mean age of the patients was $51.79 \pm 7.96$ years (Table-I). Most of the patients 97 (82.90\%) were presented with $>45$ years of age (Figure- 1 ). Mean TSH level was $3.98 \pm 0.23 \mathrm{mIU} / \mathrm{L}$ (Table-II). Mean duration of $\mathrm{HCV}$ was $6.42 \pm 1.67$ months (Table-III).

There were 77 (65.80\%) patients with $>5$ months of duration of HCV (Figure-3).Mean duration of treatment was $5.42 \pm 1.67$ months (Table-IV).

There were 74 (63.20\%) patients with $>4$ months of duration of treatment (Figure-4).Majority of the patients 47 (40.20\%) were housewives, followed by manual worker 30 (25.60\%), office worker 25 (21.40\%), jobless/retired 9 (7.70\%) and businessmen 6 (5.10\%) (Figure-5).

Frequency of hypothyroidism was found in 62 (53\%) patients (Figure-6).

Stratification was done to see the effect of age, 
duration of $\mathrm{HCV}$, duration of treatment, gender and occupation on the outcome. Chi-square test was applied. Results are shown in Table V-VIII.

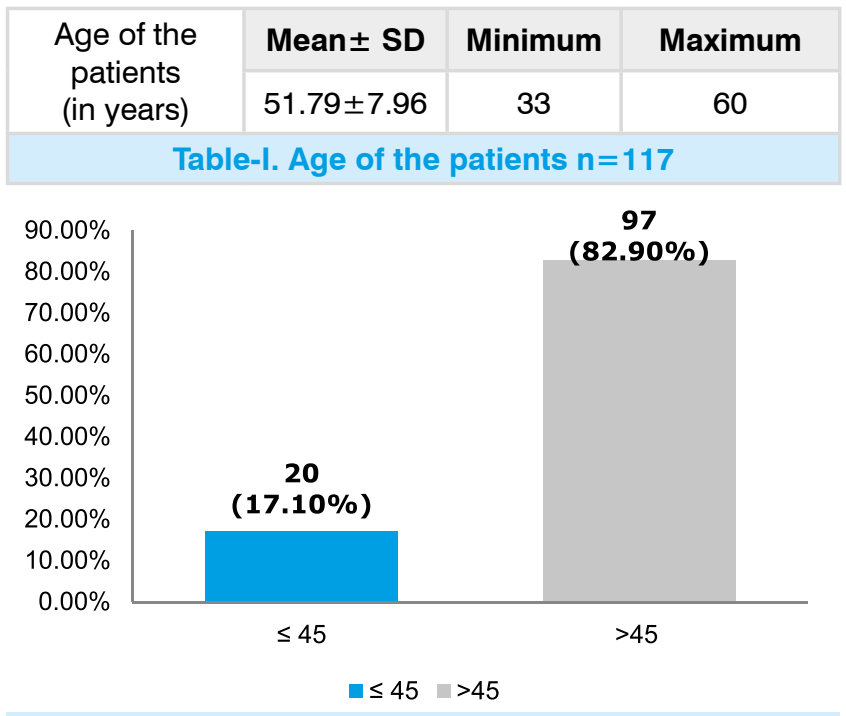

Figure-1. Age Group

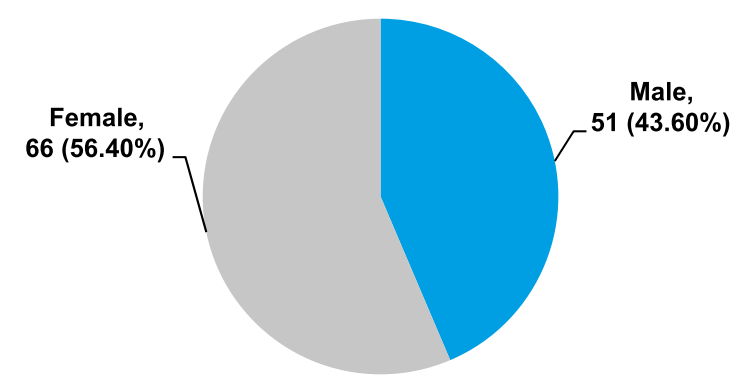

Figure-2. Gender Distribution

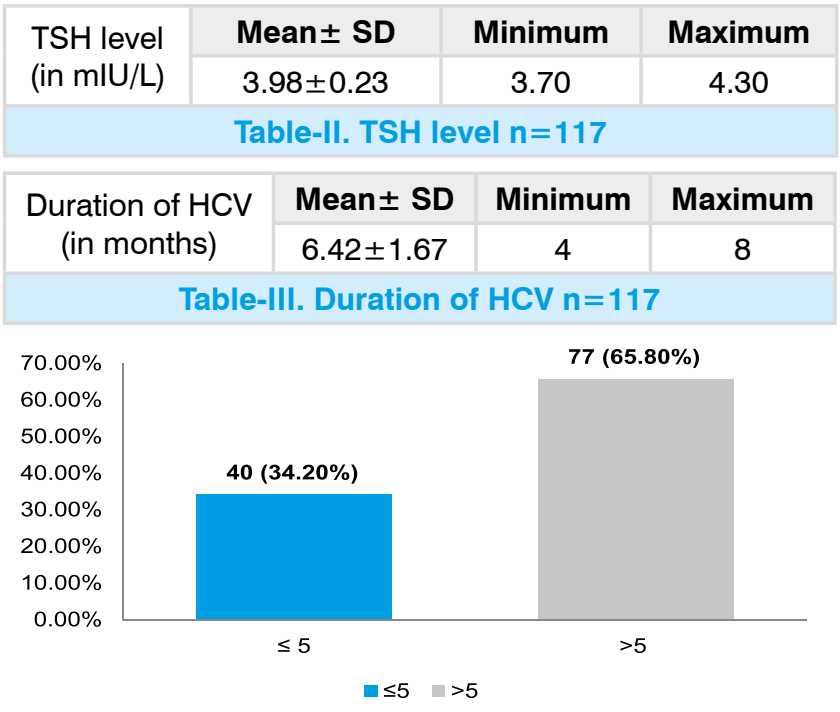

Figure-3. Duration of HCV

\begin{tabular}{|c|c|c|c|}
\hline $\begin{array}{c}\text { Duration of } \\
\text { treatment } \\
\text { (in months) }\end{array}$ & Mean \pm SD & Minimum & Maximum \\
\cline { 2 - 4 } & $5.42 \pm 1.67$ & 3 & 7 \\
\hline
\end{tabular}

Table-IV. Duration of treatment $n=117$

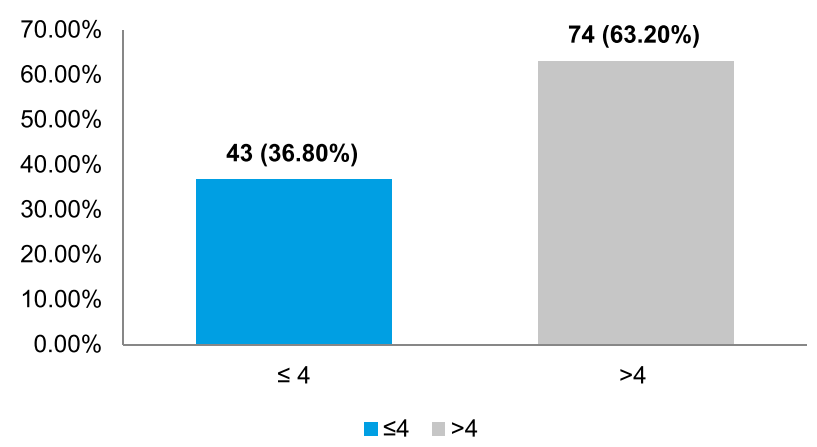

Figure-4. Duration of treatment

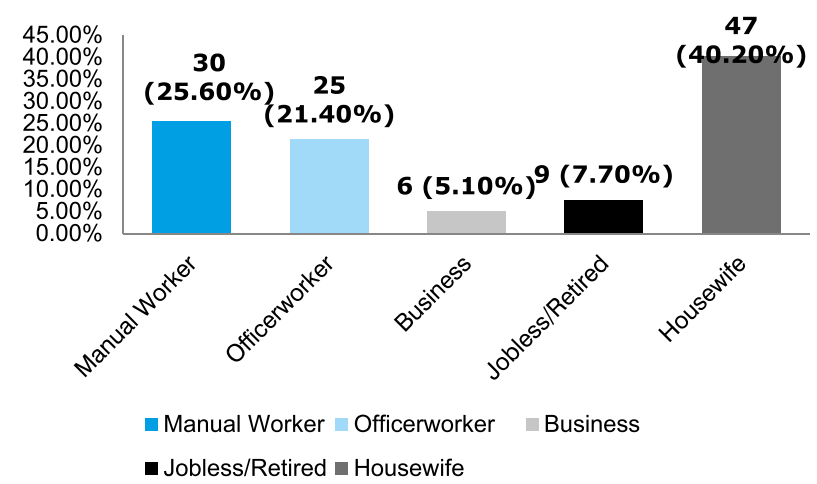

Figure-5. Occupation

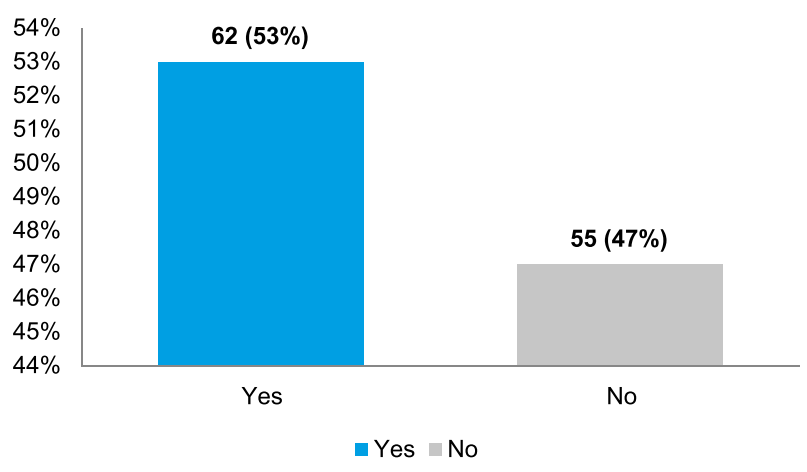

Figure-6. Hypothyroidism

\section{DISCUSSION}

In our study, Mean TSH level was $3.98 \pm 0.23$ $\mathrm{mIU} / \mathrm{L}$ and frequency of hypothyroidism was found in $62(53 \%)$ patients.

Somewhat similar results were found in other 


\begin{tabular}{|c|c|c|c|c|}
\hline \multirow{2}{*}{ Age Group } & \multicolumn{2}{|c|}{ Hypothyroidism } & \multirow{2}{*}{ Total } & \multirow{2}{*}{ p-value } \\
\hline & Yes & No & & \\
\hline$\leq 45$ & $12(60)$ & $8(40)$ & $20(100)$ & \multirow{3}{*}{0.624} \\
\hline$>45$ & $50(51.5)$ & $47(48.5)$ & $97(100)$ & \\
\hline Total & $62(53)$ & $55(47)$ & $117(100)$ & \\
\hline \multicolumn{5}{|c|}{ Table-V. Comparison of age with hypothyroidism $n=117$} \\
\hline \multirow{2}{*}{ Duration of HCV } & \multicolumn{2}{|c|}{ Hypothyroidism } & \multirow{2}{*}{ Total } & \multirow{2}{*}{ p-value } \\
\hline & Yes & No & & \\
\hline$\leq 5$ & $25(62.5)$ & $15(37.5)$ & $40(100)$ & \multirow{3}{*}{0.173} \\
\hline$>5$ & $37(48.1)$ & $40(51.9)$ & $77(100)$ & \\
\hline Total & $62(53)$ & $55(47)$ & $117(100)$ & \\
\hline \multicolumn{5}{|c|}{ Table-VI. Comparison of duration of HCV with hypothyroidism $n=117$} \\
\hline \multirow{2}{*}{ Gender } & \multicolumn{2}{|c|}{ Hypothyroidism } & \multirow{2}{*}{ Total } & \multirow{2}{*}{ p-value } \\
\hline & Yes & No & & \\
\hline Male & $51(100)$ & $0(0)$ & $51(100)$ & \multirow{3}{*}{0.001} \\
\hline Female & $11(16.7)$ & $55(83.3)$ & $66(100)$ & \\
\hline Total & $62(53)$ & $55(47)$ & $117(100)$ & \\
\hline \multicolumn{5}{|c|}{ Table-VII. Comparison of gender with hypothyroidism $n=117$} \\
\hline \multirow{2}{*}{ Occupation } & \multicolumn{2}{|c|}{ Hypothyroidism } & Tata & \multirow{2}{*}{ p-value } \\
\hline & Yes & No & lotal & \\
\hline Manual Worker & $30(100)$ & $0(0)$ & 30 (100) & \multirow{6}{*}{0.001} \\
\hline Office Worker & $15(60)$ & $10(40)$ & 25 (100) & \\
\hline Business & $6(100)$ & $0(0)$ & $6(100)$ & \\
\hline Jobless/Retired & $9(100)$ & $0(0)$ & $9(100)$ & \\
\hline Housewives & $2(4.3)$ & 45 (95.7) & 47 (100) & \\
\hline Total & $62(53)$ & $55(47)$ & $117(100)$ & \\
\hline
\end{tabular}

study as well. Out of 68 patients 38(55.9\%) had TSH level $>5 \mathrm{mlU} / \mathrm{L}$ is Hypothyroidism. ${ }^{16,17}$ Whereas in other study 1 out of 32 that is $3.12 \%$ developed hypothyroidism. ${ }^{18,19}$

In 2003 different studies were conducted with pegylated interferon treated hcv virus genotype 1 and $4-5$ results were found that 35 to $40 \%$ percent of patient have hypothyroidism. ${ }^{20,21,22}$

In our study interferon alpha used with ribaviron in hcv treated patients from three to six month results shows that $63 \%$ percent have developed sign and symptoms of thyroid dysfunction and confirmed thru thyroid stimulating hormone (TSH) and Tri-iodo-thyroninie (T3), Tetra-iodo-thyroninie (T4). ${ }^{23,24}$
In relation to interferon treated pts in different study shows that female have more hypothyroidism than male pts while in our study table-l and figure-3 shows that male have more adverse feature of hypothyroidism. ${ }^{25,26}$

Many different study were conducted through population survey that shows that hepatitis $\mathrm{c}$ virus directly not involved in thyroid abnormality. $27,28,29$ In my study total number of patients 117 out of them 51 (43.60\%) males and 66 (56.40\%) females shown figure-2. Mean age of the patients was $51.79 \pm 7.96$ years (Table-II). Most of the patients $97(82.90 \%)$ were presented with $>45$ years of age were shown in figure-1. Mean TSH level was $3.98 \pm 0.23 \mathrm{mIU} / \mathrm{L}$ were demonstrated in Table-III. 
Mean duration of HCV was $6.42 \pm 1.67$ months were described in Table-IV.

There were 77 (65.80\%) patients with $>5$ months of duration of $\mathrm{HCV}$ seen in figure-3. Mean duration of treatment was $5.42 \pm 1.67$ months seen in figure-5.

There were 74 (63.20\%) patients with $>4$ months of duration of treatment in figure (4).Majority of the patients 47 (40.20\%) were housewives, followed by manual worker 30 (25.60\%), office worker 25 (21.40\%), jobless/retired 9 (7.70\%) and businessmen $6(5.10 \%)$ at figure-5.

Frequency of hypothyroidism was found in 62 (53\%) patients in figure-6.

\section{CONCLUSION}

The frequency of hypothyroidism in patients with viral hepatitis receiving interferon treatment was found to be 62 (53\%). Interferon's anti viral drugs directly inhibits the enzyme pathway of thyroid hormone metabolism which leads abnormality increase or decrease tri-iodo-thyroninie and tetraiodo-thyroninie level in blood, but prevalence of hypothyroidism is more found in all study of Asia.

So our aim and objective of this study to prevent or minimize the complication of interferon treated pts in HCV virus in Pakistan.

Copyright@ 30 Aug, 2016.

\section{REFERENCES}

1. Negro F, AlbertiA. The global health burden of hepatitis C virus infection. Liver Int. 2011; 31(Supp12):1-3.

2. Shepard CW, Finelli L, Alter MJ. Global epidemiology of hepatitis C virus infection. Lancet Infect Dis. 2005; 5(9):558-67.

3. Ghany MG, Strader DB, Thomas DL, Seeff LB. Diagnosis, management, and treatment of hepatitis C: an update. Hepatology. 2009; 49(4):1335-74.

4. McHutchison JG, Lawitz EJ, Shiffman ML, Muir AJ, Galler GW, Mc-Cone J, et at. Peginterferon alfa-2b or alfa-2a with ribavirin for treatment of hepatitis $\mathbf{C}$ infection. N Engl J Med. 2009; 361(6):580-93.

5. Fried MW, Shiffman ML, Reddy KR, Smith C, Marinos $\mathrm{G}$, Goncalgs al. Peginterferon alfa-2a plus ribavirin for chronic hepatitis $\mathbf{C}$ virus infection. $\mathrm{N}$ Engl $\mathbf{J}$ Med. 2002; 347(13):975-82.

6. Manns MP, McHutchison JG, Gordon SC, Rustgi VK, Shiffman M, Reindollar R, et al. Peginterferon alfa-2b plus 'ribavirin compared with interferon alfa-2b plus ribavirin for initial treatment of chronic hepatitis C: a randomised trial. Lancet. 2001, 358(9286):958-65.

7. Sokal EM, Bourgois A, Stephenne X, Silveira T, Porta G, Gardovska D, et al. Peginterferon alfa-2a plus ribavirin for chronic hepatitis $\mathbf{C}$ virus infection in children and adolescents. J Hepatol. 2010; 52(6):827-31.

8. Antonelli A, Ferri C, Ferrari SM, Colaci M, Sansonno $D$, Fallahi P. Endocrine manifestations of hepatitis $C$ virus infection. Nat ClinPractEndocrinolMetab. 2009; 5(1):26-34.

9. Antonelli A, Ferri C, Pampana A, Fallahi P, Nest! C, Pasquini $M$, et al. Thyroid disorders in chronic hepatitis C. Am J Med. 2004:117(1):10-3.

10. Prummel MF, Laurberg P. Interferon-alpha and autoimmune thyroid disease. Thyroid. 2003; 13(6).547-51.

11. Dixit NM, Perelson AS. The metabolism, pharmacokinetics and mechanisms of 1 antiviral activity of ribavirin against hepatitis $\mathbf{C}$ virus. Cell Mol Life Sci. 2006; 63(7-8):332-342.

12. Snell NJ. Ribavirin current status of a broad spectrum antiviral agent. Expert OpinPharmacother. 2001; 2(8).1317-24.

13. Tomer $\mathrm{Y}$, Blackard JT, Akeno $\mathrm{N}$. Interferon alpha treatment and thyroid dysfunction EndocrinolMetabClin North Am. 2007; 36(4):1051-66.

14. Andrade LJ, Atta AM, Atta ML, Mangabeira CN, Parana $R$. Thyroid disorders in patients with chronic hepatitis C using interferonalpha and ribavirin therapy. Braz J Infect Dis 2011; 15(4):377-81.

15. Costelloem SJ, Wassef N, Schulz J, Vaghijiani T, Morris $\mathrm{C}$, Whiting $\mathrm{S}$, et al. Thyroid dysfunction in a UK hepatitis $\mathbf{C}$ population treated with interferon-alpha and ribavirin combination therapy. ClinEndocrinol (Oxf) 2010; 730:249-56.

16. Dabrowska MM, Panasiuk A, Flisiak R. Thyroid dysfunction in antiviral therapy of chronic hepatitis C. Hepatogastroenterology. 2010; 57(101):826-31.

17. Yan Z, Fan K, Fan Y, Wang X, Mao Q, Deng G, WaPi . Thyroid dysfunction in Chinese patients with chronic hepatitis $\mathbf{C}$ treated with interferon alpha: incidence, long-term outcome and predictive factors. Hepat 
Mon. 2012 Sep; 12(9):e6390.

18. Roti El, Minnelli R, Giuberti T, Matatielli S, Schianchi C, Gardini E, et at. Multiple changes in thyroid function in patients with chronic active HCV hepatitis treated with recombinant interferon-alpha. Am J Med. 1996 Nov; $101(5): 482-7$.

19. Carella C, Mazziotti G, Amato G, Braverman LE, Roti E Clinical review 169: Interferon-alpha-related thyroid disease: pathophysiological, epidemiological, and clinical aspects. J ClinEndocrinolMetab. 2004; 89(8):3656-61.

20. Prummel MF, Laurberg P. Interferon-dand autoimmune thyroid disease. Thyroid. 2003;13:547-551

21. Okanoue T, Sakamoto S, Itoh Y, Minami M, Yasui K, Sakamoto M,et al. Side effects of high-dose interferon therapy for chronic hepatitis C. J Hepatol. 1996; 25:283-291.

22. Hsieh MC, Yu ML, Chuang WL, Shin SJ, Dai CY, Chen $\mathrm{SC}$, et al. Virologic factors related to interferon-a -induced thyroid dysfunction in patients with chronic hepatitis C. Eur J Endocrinol. 2000;142:431-437

23. Lisker-Melman M, Di Bisceglie AM, Usala SJ, Weintraub $B$, Murray LM, Weissel M. Development of thyroid disease during therapy of chronic viral hepatitis with interferon a. Gastroenterology. 1992; 102:2155-2160.

24. Watanabe $U$, Hashimoto $E$, Hisamitsu T, Obata $H$,
Hayashi N. The risk factor for development of thyroid disease during interferon-atherapy for chronic hepatitis C. Am J Gastroenterol. 1994;89:399

25. Tani J, Mori K, Hoshikawa S, Nakazawa T, Satoh J, Nakagawa Y, Ito S, Yoshida K. Prevention of lymphocytic thyroiditis in iodide-treated nonobese diabetic mice lacking interferon regulatory factor-1. Eur J Endocrinol. 2002;147:809-814

26. Mazziotti G, Sorvillo F, Stornaiuolo G, Rotondi M, Morisco F, Ruberto $M$, et al. Temporal relationship between the appearance of thyroid autoantibodies and development of destructive thyroiditis in patients undergoing treatment with two different type-1 interferons for HCV-related chronic hepatitis: a prospective study. J Endocrinol Invest. 2002; 25:624630.

27. Fried MW, Shiffman ML, Reddy KR, Smith C, Marinos G, Goncales Jr FL, et al. Peginterferon-a2a plus ribavirin for chronic hepatitis $\mathbf{C}$ virus infection. $\mathrm{N}$ Engl $\mathrm{J}$ Med. 2002; 347:975-982.

28. Russo MW, Fried MW. Side effects of therapy for chronic hepatitis C. Gastroenterology. 2003; 124:17111719.

29. Dalgard O, Bjoro K, Hellum K, Myrvang B, Bjoro T, Haug $E$, Bell $H$. Thyroid dysfunction during treatment of chronic hepatitis $\mathbf{C}$ with interferon a: no association with either interferon dosage or efficacy of therapy. $J$ Intern Med. 2002; 251:400-406.

\section{AUTHORSHIP AND CONTRIBUTION DECLARATION}

\begin{tabular}{|c|c|c|c|}
\hline Sr. \# & Author-s Full Name & Contribution to the paper & Author $=\mathbf{s}$ Signature \\
\hline 1 & Dr. Aisha Rajput & $\begin{array}{l}\text { Collection of data / } \\
\text { Supervision }\end{array}$ & \\
\hline 2 & Dr. Bagwan Das & $\begin{array}{l}\text { Superise \& Collecting } \\
\text { refference }\end{array}$ & \\
\hline 3 & Dr. Santosh Kumar & $\begin{array}{l}\text { Work on B collection \& } \\
\text { result }\end{array}$ & \\
\hline 4 & Dr. Rafique Ansari & Introduction discusison & \\
\hline 5 & Dr. Beshan Kumar & Formulating collection & \\
\hline 6 & Abdul Qadeer & Support to data & \\
\hline
\end{tabular}

